\title{
First Record of Lepidoptera in Southern Brazilian Salt Marshes
}

\author{
Marcel Lucas Gantes ${ }^{\bowtie}$, Daiane Silveira Carrasco \& Fernando D’Incao
}

Universidade Federal do Rio Grande, e-mail: marcelgantes@hotmail.com (Autor para correspondência ${ }^{\bowtie}$ ), daiane_carrasco@hotmail.com, docdinca@furg.br.

\section{EntomoBrasilis 6(2): 160-161 (2013)}

Abstract. Salt marshes are highly productive environments and economic importance, however, little attention is given to insects in this ecosystem, and its entomofauna unknown in Brazil. Thus, it is the first record for lepidopteran Southern Brazilian coastal marshes ( $32^{\circ} \mathrm{O} 1^{\prime} \mathrm{S}$; $\left.052^{\circ} \mathrm{O} 6{ }^{\prime} \mathrm{W}\right)$.

Keywords: Butterflies; estuary; moths.

\section{Primeiro Registro de Lepidoptera em Marisma no Sul do Brasil}

Resumo. Marismas são ambientes de grande produtividade e importância econômica, no entanto, pouca atenção é dada aos insetos neste ecossistema, sendo sua entomofauna desconhecida no Brasil. Assim, faz-se o primeiro registro de lepidópteros para as marismas do sul do Brasil $\left(32^{\circ} \mathrm{O} 1^{\prime} \mathrm{S} ; 052^{\circ} \mathrm{O} 66^{\prime} \mathrm{W}\right)$.

Palavras-chave: Borboletas; estuário; mariposas.

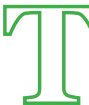
The Order Lepidoptera has 150,000 species approximately, which 20,000 are butterflies (MielKe \& CASAGRANDE 1997). In the Neotropics there are nearly 38,000 species of moths and 8,000 of butterflies (HEPpNer 1991); and in Brazil there are about 25,000 species of moths and 3,300 butterflies (BROwN 1996).

In Brazil, data about the occurrence and distribution of Lepidoptera are scarce for many ecosystems, mainly in coastal areas. This lack of information makes difficult the evaluation and monitoring of priority areas for conservation (BALMER 2002), once this group has a huge insect-plant interaction, being potential biological indicators of health status of natural plant communities (Мотта 1993).

Currently, several ecological essays about life cycle of aquatic animals in estuaries have been developed for dealing with high fertility areas; though, poor attention has been given to the insects in ecological reviews of coastal habitat (ADAM 1990). Moreover, with rising habitat destruction, it becomes increasingly important to conduct researches on biological diversity and ecosystems (WiLSON 2000).

Salt marshes are among the wetlands of international importance in the context of conservation (SÃO PAULO 1997) and they are spread over almost the entire Brazilian coast (CosTA \& DAVY 1992). The largest expanses of salt marshes in Brazil are found in the states of Santa Catarina (Soriano-SiERra 1990; PANITZ 1992) and Rio Grande do Sul (Costa et al. 1997), where 95\% of salt marsh area in the state lies in the extreme south, bordering the municipalities of Rio Grande and São José do Norte (CosTA \& DAVY 1992).

Although insects are abundant throughout the salt marsh (CosTA 1998), data on interactions between insects and plants in the Brazilian coastal marshes are nonexistent. Therefore, this essay has the purpose of to making the first record of Lepidoptera in a
Brazilian salt marsh.

Collections were made in the Ilha da Pólvora $\left(32^{\circ} \mathrm{O} 1^{\prime} \mathrm{S} ; 052^{\circ} \mathrm{O} 6{ }^{\prime} \mathrm{W}\right)$ (Figure 1) which lies in Lagoa dos Patos estuary. It has an area of 45 ha, almost entirely covered by salt marshes.

The meteorological data were provided by Estação Meteorológica da Praticagem da Barra do Rio Grande (32 08,2 "S; $052^{\circ} 06,2$ "W).

The salt marshes are colonized by Spartina alterniflora (Loisel) in the frequent (frequently) flooded part, with the largest extent of the marshes dominated by Spartina densiflora (Brong) and Scirpus maritimus (Lam) (SEELIGER et al. 2004). The higher marshes are rarely flooded and receive the coverage of the bush Myrsine parvifolia (A. DC), known as capororoca. The woods of capororoca are mixed plant communities (i.e. with herbaceous plants, climbing plants and bushes). These amphibian trees may reach between 2-3 $\mathrm{m}$ tall, even though, they lack a dense canopy, which allows the formation of a significant herbal extract (SEELIGER et al. 2004).

The specimens were captured with an entomological net to rest beneath the woods of capororoca, taken to the laboratory, mounted and identified with the aid of expert guides (CANNALS 2003).

Agraulis vanillae incarnata (N. Riley), Papilio cresphontes (Cramer); Eurema deva (Doubleday) were collected at noon, on

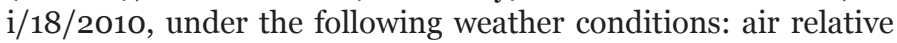
humidity: $64 \%$; precipitation: 0 ; average temperature: $28.6^{\circ} \mathrm{C}$; wind: $22 \mathrm{~km} / \mathrm{h}$ and North.

The caterpillar Megalopyge urens (Berg) was collected grazing on the leaves of $M$. parvifolia at 2:20 pm, on ii/o8/2010, with

Agência(s) de Financiamento: CAPES 


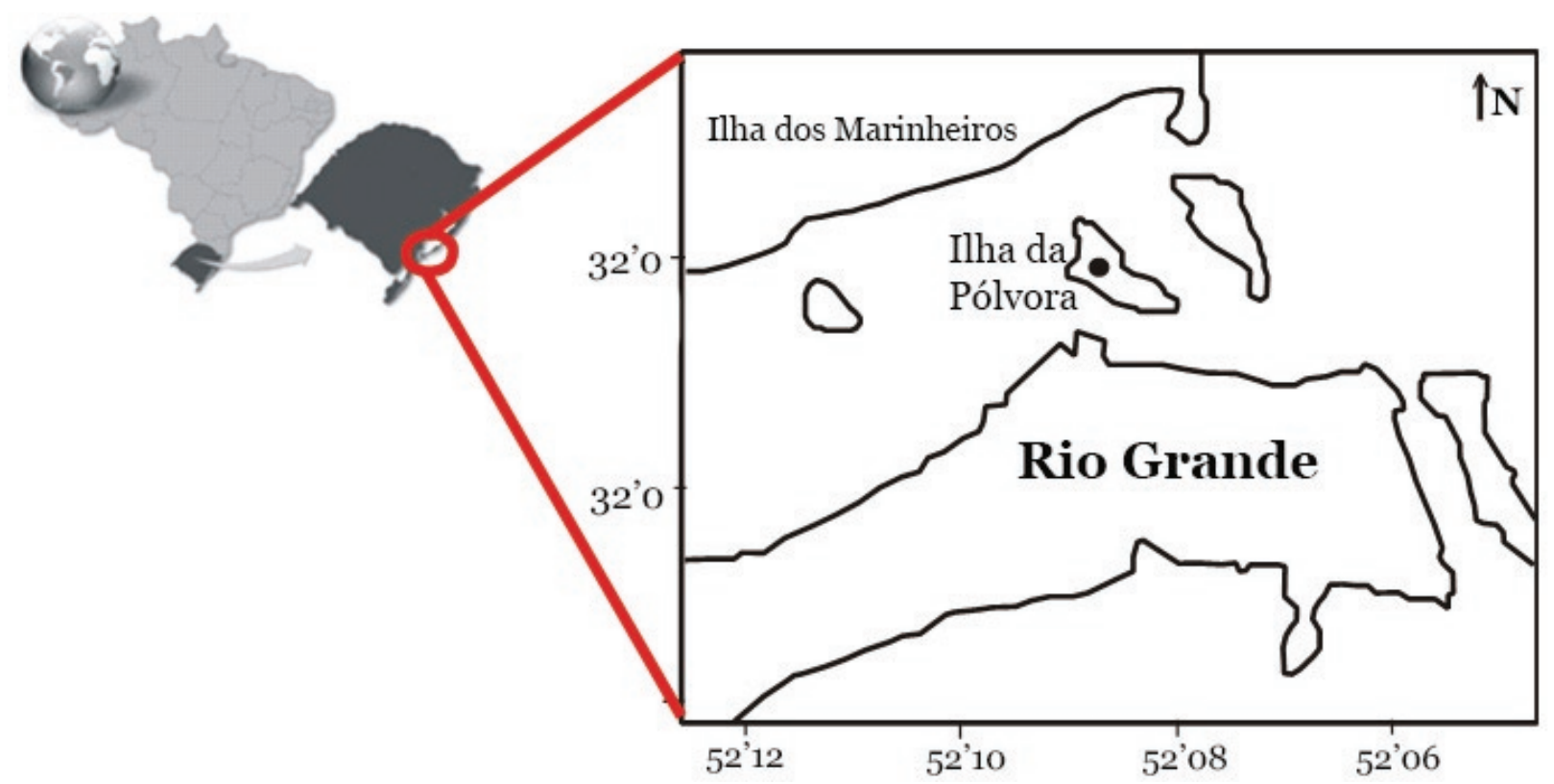

Figure 1. Study area - Ilha da Pólvora - Estuary of Lagoa dos Patos (Source: Laboratory of Decapod Crustaceans - Sector Entomology).

the environmental parameters: air relative humidity: $82 \%$; precipitation: 0 ; average temperature: $27.3^{\circ} \mathrm{C}$; wind: $19 \mathrm{~km} / \mathrm{h}$ and west-southwest.

\section{REFERENCES}

Adam, P., 1990. Saltmarsh Ecology. New York, Cambridge University Press, $461 \mathrm{p}$.

Balmer, O., 2002. Species lists in ecology and conservation: abundances matter. Conservation Biology 16: 1160-1161.

Brown, K.S., 1996. Diversity of Brazilian Lepidoptera: history of study, methods for measurement, and use as indicator for genetic, specific and system richness, p. 221-253. In: C.E.M. Bicudo \& N.A. Menezes (eds.). Biodiversity in Brazil: a first approach. São Paulo, CNPq, 326p.

Canals, G.R., 2003. Mariposas de Misiones. Buenos Aires, L.O.L.A., 492 p.

Costa, C.S.B., 1998. Marismas Irregularmente Alagadas, p. 8287. In: Seeliger, U. C., Odebrecht \& J.P. Castello (eds.). Os Ecossistemas Costeiro e Marinho do Extremo Sul do Brasil. Rio Grande, 326p.

Costa, C.S.B., U. Seeliger, C.P.L. Oliveira \& A.M.M. Mazo, 1997. Distribuição, funções e valores das marismas e pradarias submersas no estuário da Lagoa dos Patos (RS, Brasil). Atlântica, 19: 65-83.

Costa, C.S.B. \& A.J. Davy, 1992. Coastal saltmalsh communities of Latin America, p. 179-199. In: Seeliger, U. (ed.). Coastal plant communities of Latin America. San Diego, Academic Press, 391p.

Heppner, J.B., 1991. Faunal regions and the diversity of Lepidoptera. Tropical Lepidoptera, 2: 1-85.

Mielke, O.H.H. \& M.M. Casagrande, 1997. Papilionoidea e Hesperioidea (Lepidoptera) do Parque Estadual do Morro do Diabo, Teodoro Sampaio, Brasil, com notas taxonômicas sobre Hesperiidae. Revista Brasileira de Zoologia, 14: 9671001.

Motta, C.S., 1993. Mariposas esfingídeas (Lepidoptera: Sphingidae) da Amazônia Brasileira e o Meio Ambiente, p. 141-146. In: Ferreira, E.J.G. Santos, G.M. Leão, E.L.M. \& L.A. Oliveira (eds.). Bases Científicas para Estratégias de Preservação e Desenvolvimento da Amazônia - Fatos e Perspectivas, Manaus, CNPq/INPA, v. 2, 440p.

Panitz, C.M.N., 1992. Ecological aspects of a salt marsh ecosystem in Santa Catarina island, Brazil, p. 213-230. In: Seeliger, U. (ed.). Coastal plant communities of Latin America. San Diego, Academic Press, 391p.

São Paulo, 1997. Convenção de Ramsar sobre zonas úmidas de importância internacional, especialmente como habitat de aves aquáticas. Série Entendendo o meio ambiente. São Paulo, Secretaria de Estado do Meio Ambiente, v. 3, 24 p.

Seeliger, U., C. Cordazzo \& L. Barcellos, 2004. Areias do Albardão: um guia ecológico ilustrado do litoral do extremo sul do Brasil. Rio Grande, Ecoscientia, 96p.

Soriano-Sierra, E.J., 1990. Ecossistema de marismas na Lagoa da Conceição. 1. O Biótopo, p. 129-143. In: Sierra de Ledo, B. \& E. J. Soriano-Sierra (eds.). O A1:A18 da Lagoa da Conceição. Florianópolis, NEMAR/CCB/UFSC. SDM/FEPEMA, 177p.

Wilson, E.O., 2000. Foreword, p. 15-16. In: Agosti, D., J.D. Majer, L.E. Alonso \& T.R. Schultz (eds.). Ants: Standard methods for measuring and monitoring biodiversity. Washington, Smithsonian Institution Press, 390 p + xix.

\section{Recebido em: 04/o6/2012}

Aceito em: 19/o1/2013

\section{Como citar este artigo:}

Gantes, M.L., D.S. Carrasco \& F. D’Incao, 2013. First Record of Lepidoptera in Southern Brazilian Salt Marshes. EntomoBrasilis, 6(2): 160-161.

Acessível em: http://www.periodico.ebras.bio.br/ojs/index.php/ebras/article/view/241. doi:10.12741/ebrasilis.v6i2.241
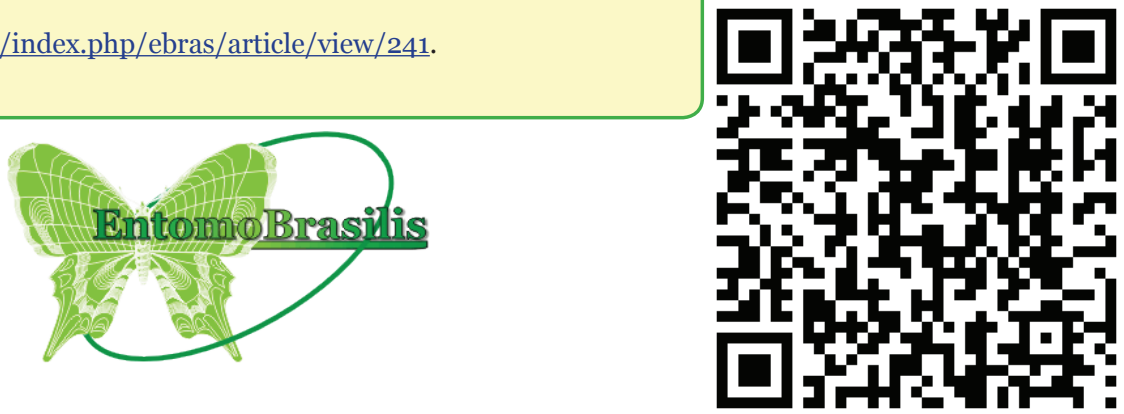